\title{
1. Introduction: governing climate relations between Europe and Asia in a restructuring world order
}

David Belis, Hans Bruyninckx, Qi Ye and Nguyen Quang Thuan

This book provides a thorough empirical study of the most fundamental dynamics, practices and policy processes involved in Europe-Asia climate relations, with a specific focus on China and Vietnam as key emerging economies. Due to double-digit economic growth and related booming greenhouse gas (GHG) emissions, major Asian developing economies such as China and, to a lesser extent, India have moved centre-stage in all important areas of global governance (Dryzek et al. 2011; Wouters et al. 2012). This restructuring of the global world order is having a profound impact on the global climate regime, as established by the 1992 United Nations Framework Convention on Climate Change (UNFCCC). Since the 2009 Copenhagen summit, China in particular has assumed a pivotal role in international climate negotiations (Grubb 2010: 127). As a result, the relationship between Asia and the most active player in the climate regime, the European Union (EU), has become a key element for future climate governance practices (Belis and Schunz 2012; Schreurs 2010: 89).

The rise of China also implies major changes for other Asian developing countries, including Vietnam. China is attempting to move away from an economic model based on infrastructure development and cheap consumer good exports, an evolution that is accelerating with the implementation of the 2011-2015 12th socio-economic Five-Year Plan (Fan et al. 2011). As the Chinese economy moves higher up the international value chain, major parts of its manufacturing industries are relocating towards other low-wage, industrializing countries in the region, such as Indonesia, Malaysia or Vietnam (Adams and Tran 2011; Mol and van Buuren 2003). Vietnam is especially important in this regard because of its geographic location, sustained economic growth and relative political stability. Countries such as Vietnam will thus be increasingly important in global climate governance and are likely to join China and the other 
BASIC countries (India, Brazil and South Africa) as main recipients of climate mitigation and adaptation assistance in the near future. In Copenhagen, importantly, the EU and other developed countries pledged to provide $\$ 30$ billion per year of fast-start finance to developing countries during the 2010-2012 period, which would build up in the 2013-2020 period to reach $\$ 100$ billion per year by 2020 .

It is, in sum, of crucial importance that lessons be drawn from current climate governance processes and practices between developed and developing countries, including the trade in emission certificates through the Clean Development Mechanism (CDM) and the EU Emissions Trading System (EU ETS). These climate governance practices and processes and the policy frameworks that define them, are inherently complex and multifaceted in nature. This book therefore focuses on in-depth and comprehensive empirical case studies, offering a unique relational perspective as elaborated upon below.

\section{EUROPE AND ASIA IN THE GLOBAL CLIMATE REGIME}

The shifting roles of developing countries and of China and Vietnam in the Asian region in particular, affect the very structure of global environmental and climate change governance (Biermann 2005, 2006; Keukeleire and Bruyninckx 2011). Since the adoption of the UNFCCC in 1992, negotiating parties have been divided into two different categories: Annex I and non-Annex I parties or developed and developing countries respectively (Bodansky 1993; United Nations 1992). Until the end of the first commitment period of the 1997 Kyoto Protocol (2008-2012), no emission mitigation targets have been required from non-Annex I countries (United Nations 1998). This situation is questioned due to rapidly rising emission rates in many developing countries, including China and Vietnam (IEA 2011; Qi 2011).

The European Union, in contrast, has already assumed initial climate mitigation commitments, with the Kyoto Protocol targets within reach, and is attempting to establish comprehensive long-term policies to effectively meet its historical responsibilities. In the global climate regime, the European Union can more specifically be considered a lead actor for the following reasons: (1) it has developed the most comprehensive and coherent set of climate change policies; (2) it has developed the most prominent market-based instrument, the EU ETS; (3) it has been one of the driving forces of international climate negotiations; and (4) it is regarded by the other important actors (the United States, BASIC countries, G77) as the 
lead actor (Bruyninckx et al. 2011; Gupta and Ringius 2001; Schreurs 2008; Wurzel and Connelly 2011).

In the absence of any meaningful participation by the United States (US) in the climate regime, the EU is expected to retain its leadership position and continue to be the most active player in the developed world, not in the least because of its 'flagship' climate policy instrument, the EU ETS (Delbeke 2006; Skjærseth and Wettestad 2009). The EU ETS provides the single largest source of demand for emission reduction certificates worldwide, covering over 11000 energy-intensive installations across the EU and about 40 per cent of its overall GHG emissions (European Commission 2009; Point Carbon 2012). It is an essential part of the EU's 'climate and energy package', a set of laws to bolster its unilateral pledge of 20 per cent emission reductions by 2020 (EU 2009a, 2009b; Jordan et al. 2010; Oberthür and Pallemaerts 2010). Implementing the trading scheme, however, has not always been without difficulties, especially in the early days of the ETS (2005-2008), with overallocation and other concerns continuing up to the present (Carbon Market Institute 2012: 11-14; Skjærseth 2010: 305).

Internationally, the European Union is attempting to invigorate the international negotiations process after the failure in Copenhagen to reach a global agreement. In Durban, 2011, it agreed to a second commitment period of the Kyoto Protocol, on the condition that a future global agreement would be negotiated by 2015 and come into force in 2020 (UNFCCC 2011b). The Durban Platform assures the continuity of international negotiations, but because of the current positions of key strategic actors such as the US and China, progress is likely to remain slow at best (Conrad 2012: 435; Grubb 2010). Many observers, therefore, are looking to other venues to push forward international talks and/or action on the ground such as the G20, the Global Business Council and the World Trade Organization (WTO) or promote bottom-up approaches such as city networks, (voluntary) carbon markets or other local, national and/or regional governance arrangements that move beyond a state-centric approach (Bulkeley 2011; Falkner et al. 2010; Schreurs 2008; Spaargaren et al. 2006; Qi et al. 2008).

Due to this tangled web of interdependent stakeholders and interests, it is of crucial importance that the governance processes and practices themselves, as well as the deeper contextual reasons behind the behaviour of the variety of actors involved, be understood. The initiatives, actions and anticipatory measures taken by all of these players will significantly influence the features of the future climate regime and its governance practices.

One of the most prominent - and controversial - of these multilateral practices so far consists of emissions trading and offsetting between developing and developed countries. The CDM is the key instrument 
in that regard. Established as one of three flexible mechanisms in the Kyoto Protocol (the other two being international emissions trading and joint implementation), the CDM is the first global attempt to address a global environmental public goods problem with a market-based mechanism (Cole 2012; Grubb et al. 1999). The mechanism provides a carbon credit market where sellers, located exclusively in developing countries, can generate and issue Certified Emission Reductions (CERs) that can be sold to buyers located in developed countries (United Nations 1998; Yamin 2005). Since 2004, it has grown rapidly and is now an important component of developed country government (for example EU member states) and private firm compliance strategies for the Kyoto Protocol, particularly within the EU ETS (Lütken and Michaelowa 2008; Meckling 2011).

The CDM also features prominently in EU-China climate relations. Collaboration on and capacity building in CDM implementation constituted a significant element of the 2005 EU-China Partnership on Climate Change (EU 2005, 2012; MOF 2006). In the following years, the EU and China, respectively, became the single largest source of demand and of supply of CERs in the global carbon market (Chang et al. 2012; Schröder 2012; UNFCCC 2012). However as China's global role became apparent in Copenhagen, other processes and issues became increasingly important. The development of renewable energy and the issue of energy security, for instance, began to feature high on the bilateral political agenda (Belis and Schunz 2012; de Matteis 2010; Fox and Godement 2009). The choice between a carbon tax or emissions trading as the principal climate mitigation instrument is another area of mutual interest (Andersen and Ekins 2009; Cao 2011; Kreiser et al. 2011). European and Chinese policymakers, academics and business representatives are attempting to build up concrete cooperation in all of these areas. In that context, most observers and policymakers note an emerging consensus around the need for a transition towards a low-carbon economy or society (Bruyninckx 2010; Fan et al. 2011; Qi 2011; Zhang 2011a).

The challenges that China faces in making this transition are daunting. Sustaining near double-digit economic growth rates for the past three decades has put severe pressures on both the local and global environment (Carter and Mol 2007). A substantial part of these environmental impacts stems from China's highly unsustainable system of energy consumption and production (Herberg 2009: 285-286). In 2011, China consumed an estimated total of 2436.01 million tonnes of oil equivalent, with 68.4 per cent originating from the combustion of coal. Renewable energy (excluding hydropower and nuclear energy) amounted to less than 1 per cent of the total (National Bureau of Statistics of China 2012; see Figure 1.1). 


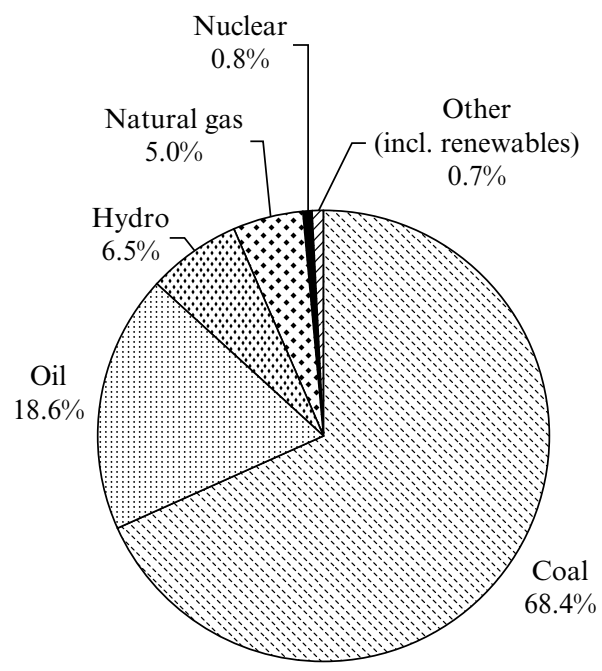

Source: Adapted from National Bureau of Statistics of China (2012)

Figure 1.1 Total primary energy consumption in China by fuel type, 2011

In the late 2000s, China not only became the world's largest energy consumer and second largest economy, but also overtook the United States as the largest source of GHG emissions, with a total of 8.3 billion tonnes of emitted carbon dioxide $\left(\mathrm{CO}_{2}\right)$ from the consumption of energy in 2010, making up 26.2 per cent of the world total. The most populous country in the world even reached per capita emission levels close to those of the European Union (EIA 2012; see Table 1.1). Perhaps due to the sheer level of mitigation potential, China has quickly become the most important developing nation engaged in emissions trading through the CDM (Schröder 2012; United Nations 2012; Zeng 2010). In view of these developments, China faces serious international pressure to assume globally agreed mitigation targets (Qi 2011: 6; Walsh et al. 2011: 263; Zhang 2011b: 247-249). When it does, its eligibility for hosting CDM projects and enjoying other non-Annex I party benefits will become questionable.

So far, however China has refused to commit to binding emission reduction targets. Indeed, it is often argued that China remains hesitant to fully embrace its new status as a global actor (Conrad 2012; Harris 2011: 12). China did commit to voluntary targets (Nationally Appropriate Mitigation Actions, NAMAs) in the Copenhagen and Cancun deals under the so-called 'pledge and review approach'. China pledged to reduce carbon emissions per unit of GDP by 40-45 per cent, based on 2005 levels, 
Table $1.1 \mathrm{CO}_{2}$ emissions from the consumption of energy, 2010

\begin{tabular}{lccc}
\hline & $\begin{array}{r}\text { Total } \mathrm{CO}_{2} \text { emissions } \\
\left(\text { million tonnes } \mathrm{CO}_{2}\right)\end{array}$ & $\begin{array}{c}\text { Per capita } \mathrm{CO}_{2} \text { emissions } \\
\left.\text { (tonnes } \mathrm{CO}_{2}\right)\end{array}$ & $\begin{array}{c}\text { Share of world } \\
\text { total }(\%)\end{array}$ \\
\hline US & 5610 & 18.08 & 17.7 \\
EU-27 & 3948 & 8.56 & 12.4 \\
China & 8321 & 6.26 & 26.2 \\
Vietnam & 113 & 1.26 & 0.4 \\
World & 31780 & 4.63 & 100.0 \\
\hline
\end{tabular}

Source: Adapted from EIA (2012).

and to heavily invest in non-fossil fuel energy so as to reach a 15 per cent share of total primary energy consumption in 2020 or roughly twice as much as in 2011 (National Bureau of Statistics of China 2012; UNFCCC 2010, 2011a; see Figure 1.1).

It would be a mistake, however, to focus exclusively on the large emerging economies. As a result of rapid economic growth and booming GHG emissions, smaller developing countries in Southeast Asia such as Vietnam are becoming key actors in the effective management of GHG emissions as well. As China attempts to simultaneously make the transformation towards a low-carbon society and move its economy higher up the international value chain (Fan et al. 2011), Vietnam, as one of the region's key emerging economies, is likely to become an important recipient of mitigation and adaptation assistance from developed countries (Asian Development Bank 2009: 150-151; IPCC 2007). Other Southeast Asian countries such as Indonesia, Malaysia and Thailand are in a similar situation, but Vietnam is of particular interest for economic, political and geographical reasons.

Vietnam, with a population of 91 million, or about 10 million inhabitants more than Germany, has seen average annual GDP growth of close to 7 per cent over the past decade (CIA 2012; World Bank 2012a). It joined the WTO in 2007 and was able to withstand the effects of the 1997 Asian financial crisis relatively well. At the time of writing in 2012, Vietnam's economic growth is being hampered by the global economic and financial crisis that started in 2008-2009, but its overall macroeconomic situation is stable and prospects remain relatively strong (Mckinsey Global Institute 2012; World Bank 2012b). Vietnam's economic success is in no small part due to it being geographically located just south of Guangxi province, Guangdong province and Hong Kong, the heartland of China's economic boom (see Enright et al. 2005), and, due to its extended $3444 \mathrm{~km}$ coastline, providing direct access to major international trade routes. In addition, 
Table 1.2 Selected economic indicators, 2011

\begin{tabular}{lccrrr}
\hline & $\begin{array}{c}\text { GDP } \\
\text { (billion dollar) }\end{array}$ & $\begin{array}{c}\text { GNI/capita } \\
\text { (PPP, dollar) }\end{array}$ & $\begin{array}{c}\text { Agriculture } \\
\text { (share /GDP) } \\
\text { (in \%) }\end{array}$ & $\begin{array}{c}\text { Industry } \\
\text { (share /GDP) } \\
\text { (in \%) }\end{array}$ & $\begin{array}{c}\text { Services } \\
\text { (share /GDP) } \\
\text { (in \%) }\end{array}$ \\
\hline US & 15094 & 48890 & $(+/-) 1$ & $(+/-) 20$ & $(+/-) 80$ \\
EU-27 & 17552 & 30745 & $1-5$ & $20-30$ & $65-80$ \\
China & 7298 & 8430 & 9 & 44 & 46 \\
Vietnam & 123 & 3260 & 20 & 41 & 40 \\
\hline
\end{tabular}

Source: Adapted from World Bank (2012a).

Vietnam has experienced a relatively stable political environment under the Communist Party, particularly since the enactment of its doi moi (renovation) policy in 1986 (Beresford 2008: 221; Fforde 2009). As a consequence of the ongoing reform process, Vietnam's gross national income (GNI) per capita (on the basis of purchasing power parity, PPP) reached $\$ 3260$ and it ranks as a lower-middle-income country with a total GDP of $\$ 123$ billion as of 2011 (World Bank 2012a; see Table 1.2).

In some respects, Vietnam finds itself in a similar socio-economic situation to that of an average Chinese province (Mol and van Buuren 2003; Thayer 2010: 392). The importance of agriculture as a share of Vietnam's GDP is shrinking, while the industrial and service sectors are booming. Due to rising labour and capital costs in China's richest provinces (including Guangdong), industrial relocation from China towards Southeast Asian countries such as Vietnam has taken off in recent years. Compared to China, however, agriculture is still twice as important and while China's industry is focusing more and more on electronics and other high-end products, the textile and footwear industry still provides the main source of exports in Vietnam (Adams and Tran 2011: 83-84; Chapponière et al. 2008: 3-6). For all of these reasons, Vietnam is set to play an increasingly important role in the Asian economy and in EU-Asia climate governance. As of early 2012, for instance, Vietnam ranks fourth in issued CERs (resulting from CDM projects) in the region, behind China, India and South Korea, but ahead of other Southeast Asian countries (UNFCCC 2012).

The development of EU-Vietnam climate relations does not, however, live up to Vietnam's present and potential importance in the field of climate mitigation and adaptation in Asia. During the past two decades, Vietnam's GHG emissions have increased sharply, from 16.8 million tonnes of energy-related $\mathrm{CO}_{2}$ emissions in 1990, over 46.1 million tonnes in 2000, to 113 million tonnes in 2010 (EIA 2012; see Table 1.1). This is 


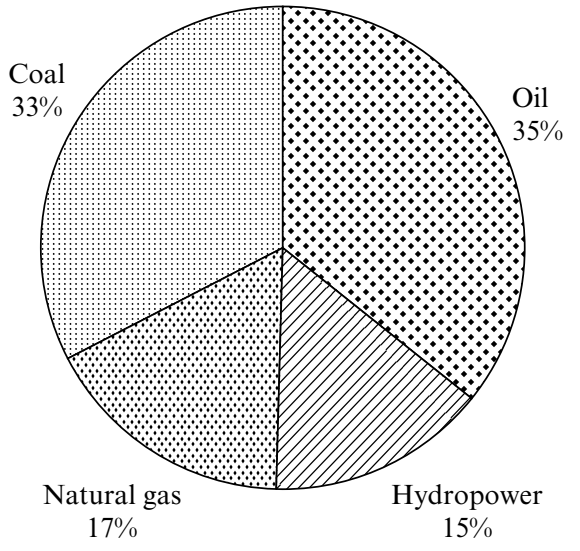

Source: Adapted from BP (2012).

Figure 1.2 Total primary energy consumption in Vietnam by fuel type, 2011

due, in large part, to a highly unsustainable energy system, largely based on oil (35 per cent), coal (33 per cent), natural gas (17 per cent) and hydropower (15 per cent) (BP 2012; see Figure 1.2). In spite of these developments, EU policy remains largely limited to mainstreaming climate change within existing development cooperation (EEAS 2007, 2009; European Commission 2012). The European Investment Bank did provide a loan of $€ 100$ million to Vietnam in 2009 to support investments that will contribute to the mitigation of climate change (EIB 2009), but most of the efforts remain in the hands of individual EU member states, notably Denmark and The Netherlands, but also France, the United Kingdom and Germany, that are each attracted by the mitigation potential in Vietnam and are pursuing their own strategies in setting up concrete bilateral climate action.

In the absence of specific EU-level instruments, the CDM constituted the main mechanism for climate mitigation assistance in EU-Vietnam climate relations throughout the 2008-2012 period (Belis and Bruyninckx 2010). After a slow start, Vietnam managed to integrate itself in the global carbon market, with more than 100 registered projects and 6.7 million issued CERs as of March 2012 (Nguyen and Tran 2010; UNFCCC 2012). However Vietnam's experiences with the CDM and climate policy in general have brought to light a number of difficulties, such as the need for capacity building and a sound governance structure, and serious transparency and procedural concerns (Fortier 2010; Nguyen et al. 2010). These 
issues are not unique to Vietnam, as the integrity of the CDM as a whole is often scrutinized in academic literature (Böhm and Dabhi 2010; Boyle et al. 2009; Lütken 2012; Van Asselt and Gupta 2009; Wara 2008; Wara and Victor 2008) and, more recently, in EU policymaking circles (Ruthner et al. 2011).

As a result, current EU legislation limits the import of CERs from CDM projects registered after 31 December 2012 to projects based in least developed countries (LDCs) or to countries that establish a bilateral agreement with the EU, as of January 2013 (European Union 2009a, 2009b). This fact and its consequences remained underreported in the media and the literature, to some extent possibly due to the rather complex and inherently political nature of the topic. After the Durban summit in late 2011, however, the ban became an absolute certainty. This means that post-2012 CERs from China or smaller players such as Vietnam will no longer be eligible. The consequences for EU-Vietnam and EU-China CDM relations are substantial. CERs from projects registered before 1 January 2013 will continue to flow into the European carbon market, but EU finance will no longer drive new CDM project development in non-LDCs during the second commitment period of the Kyoto Protocol. Other market conditions, such as an oversupply of credits in the EU ETS and reduced emissions due to the global economic and financial crisis, also undermine the (short- and mid-term) future of the mechanism. How this will then further impact upon EU-Asia relations on the bilateral and global level remains open to question. Experiences with the mechanism are crucial, however, since lessons should be drawn for future international climate finance, particularly in the post-2020 period.

\section{CONTRIBUTIONS TO THE LITERATURE}

Most of the scientific research on the political and diplomatic aspects of climate governance in the discipline of international relations has focused on the actual regime formation and functioning of the UNFCCC and on the role of the EU and the US (Bodansky 1993; Biermann 2006; Bruyninckx et al. 2011; Harris 2007; Grubb et al. 1999; Jordan et al. 2010; Oberthür and Ott 1999; Oberthür and Pallemaerts 2010) and the leadership position of the EU in particular (Gupta and Ringius 2001; Schreurs 2008; Wurzel and Connelly 2011). In recent years, new literature has emerged on the role of some of the other major actors such as Japan, Russia, India and China. This literature emphasizes the position of these countries in the Kyoto and post-Kyoto regime and a number of more instrumental implementation issues (Harris 2005; Heggelund and Backer 
2007; Keukeleire and Bruyninckx 2011; Korppoo and Luta 2009; Qi et al. 2008; Schreurs 2010; Schröder 2012; Tønnesson 2009). Some literature on climate and environmental governance in Vietnam has also emerged, focusing on the environmental consequences of Vietnam's accelerating industrialization process and its struggle to establish sound environmental and climate policy frameworks, including on the CDM (Adger et al. 2001; Belis and Bruyninckx 2010; Fortier 2010; Harris 2005; Hugé et al. 2010; Mol and van Buuren 2003; Nguyen and Dang 2010; Nguyen et al. 2010; Nguyen and Tran 2010; Sonnenfeld and Mol 2010).

However what is largely lacking in the literature is a profound study of the political interactions between key actors (see also Grubb 2010: 129). There is some research on the interactions between the US and the EU (for example Biermann 2005; Harris 2000, 2007). Yet, largely absent is research on and literature about the climate relations between the EU and other countries. This can be considered as a serious gap in our understanding of climate politics. We know from official documents, from empirical evidence as well as from extensive contacts with EU, Chinese and Vietnamese experts and the small body of existing literature, that a system of increasingly intertwined relations is developing between China, Vietnam and the EU on climate change (for example Belis and Bruyninckx 2010; Chang et al. 2012; Cooper 2012; De Cock 2011; De Matteis 2010; Fox and Godement 2009). However this has never been inventoried, mapped or analysed in the academic literature in any comprehensive manner. This is, undoubtedly, one of the most striking gaps in the swiftly expanding literature on global climate governance.

This book is a first attempt to fill this gap, while simultaneously setting the stage for further research in the field of climate politics. It is our view that the relational component is one of the most fundamental and at the same time most easily overlooked aspects of current climate governance arrangements. The study of these relationships offers a number of concrete advantages. Firstly, it offers an opportunity to fully grasp the mechanics behind specific policy instruments and strategies in practice, for example with regard to the CDM and the global carbon market, or the development of renewable energy policies and other non-fossil fuel sources such as nuclear energy and hydropower installations. Secondly, in contrast to individual country studies, a relational approach has the advantage of simultaneously analysing all decisive structural and contextual variables in each of the selected countries. Thirdly, by drawing on concrete empirical evidence while building on the existing climate governance literature, valuable lessons can be drawn for policymakers, professionals and academics alike, ranging from insights into the nature of specific policy tools over bilateral and multilateral negotiation strategies to long-term visions on the future of the climate regime. 


\section{STRUCTURE OF THE BOOK}

Part I of the book is dedicated to the evolving role of the European Union and China in the global governance of climate change. In addition to strategic positioning at the level of the UNFCCC, domestic climate and energy politics and economic background, a number of separate policy issues will be discussed as well. Part II offers a thorough review of EUVietnam climate relations and focuses on the role and functioning of the $\mathrm{CDM}$ in particular. Vietnam is an interesting case, given its extremely rapid process of industrialization - and hence increasing GHG emissions its integration in the global economy and its intensifying aspiration to be a key partner in the architecture and dynamics of the global climate change regime (UNFCCC and the Kyoto Protocol).

Chapter 2, 'The increasingly complex nature of EU-China climate relations', focuses on the intertwined and multifaceted nature of EU-China climate relations in a globalized and rapidly changing world economy. Hans Bruyninckx and Qi Ye emphasize the dramatic increase of GHG emissions in China since its accession to the WTO in 2001, and the importance of understanding current global trade flows in the context of economic but also environmental globalization. The chapter, therefore, analyses the changing character of EU-China relations since the early days of the climate regime (1992-2012) and uncovers evidence on the content and process of EU-China climate diplomacy in recent years. It concludes by suggesting pathways for future EU-China climate action in the absence of strong and effective global policies.

In Chapter 3, 'China, the European Union and global environmental governance: the case of climate change', David Belis and Simon Schunz explore the evolving role(s) of China and the European Union in global climate and environmental governance. This is done through brief singlecountry studies of China and the European Union. The second section of the chapter presents an analysis of EU-China relations in global climate governance since the early days of the climate regime (1992-2012), from the perspective of the European Union. The contribution refers to global environmental governance more generally, but consistently focuses on global climate governance as the currently most visible environmental problem. Although local and national developments are evoked, attention is centrally paid to the evolution of global climate negotiations under the United Nations umbrella.

In Chapter 4, 'Explaining the development of China's renewable energy policies: comparing wind and solar power', Sarah Van Eynde and Chang Pei-fei lay out the development of China's renewable energy policies with wind and solar power as case studies. At present, China is one 
of the world's largest investors in renewable energy and has pledged to spend $\$ 473.1$ billion on clean energy investments in the next five years. More than 57 per cent of the world's solar cells are produced in China and by 2010, China reached the same level of installed wind power capacity as countries such as Germany and Spain. China's proactive stance with regard to developing renewable energy is driven by energy security concerns, the economic benefits associated with the emerging renewable energy market and the fight against climate change itself. In addition, EU-China interactions on wind and solar energy are a vital element in current climate governance dynamics. It is therefore very interesting and important to compare the role of the European Union in wind and solar energy (policy) development in China. The chapter reveals how and why China's wind and solar energy sectors developed so rapidly and how the EU is involved in China's endeavour to develop renewable energy and identify possible ways to tackle climate change.

Kris Bachus and Cao Jing focus on the evolution of China's future climate mitigation instruments in Chapter 5, 'Cap or tax? Exploring the potential for a carbon tax or emissions trading in China'. The discussion on economy-wide climate mitigation policy instruments often comes down to a choice between a carbon tax and a carbon emissions trading mechanism. As was the case in the European Union in the early 1990s, the 'cap or tax' debate currently features very high on the agenda in China. Pilots of local emissions trading schemes are set to be launched at the beginning of 2013. However this does not imply that the idea of a nationwide carbon tax has been abandoned. This chapter, firstly, positions the cap or tax debate by comparing the two instruments from a theoretical perspective. Secondly, an overview of the use of taxes and emissions trading for other environmental challenges is provided. The chapter also analyses China's recent climate change policies and sets out the pros and cons of the two policy instruments in the particular situation of China, taking into account criteria such as institutional background and the role of local governments, general tax structure, design and implementation issues, distributional effects, international competitiveness and public support. The chapter concludes by giving future prospects and recommendations for the most effective instrument of choice for China, taking into account important side-effects such as competitiveness and distributional impact.

In the last chapter of Part I, Chapter 6, 'The governance of the CDM in China: achievements and deficiencies', David Belis, Bui Viet Hung and Nguyen Bich Thuan present an overview of China's experiences with the CDM during the first commitment period (2008-2012) of the Kyoto Protocol. The contribution starts with a general policy summary and CDM project implementation history, followed by an analysis of the 
achievements of, barriers to and deficiencies in China's CDM governance. While China is the largest political and economic power among developing countries and the largest source of GHG emissions at present, it is also the world's main recipient of climate mitigation assistance through the CDM. This is a controversial aspect of current and future climate relations with the European Union, the latter being the largest source of CDM finance. The chapter attempts to draw lessons from the case of China and offers a number of general conclusions with regard to the CDM in EU-Asia climate relations.

Part II of the book looks at the relationship between the EU and Vietnam on climate change. Whereas China is attracting large amounts of financial and technological support from industrialized countries, smaller developing countries in Southeast Asia are often disproportionately overlooked. The potential and urgency for emissions mitigation in Vietnam, however, is high and on the rise. It remains crucial, simultaneously, to select the long-term most effective and environmentally sound modes of cooperation between Asia and the EU in bilateral and multilateral climate governance. In the 2008-2012 period, the CDM occupied a central position as one of the main channels of bilateral climate action between these two regions. The study of the environmental integrity, regulatory functioning and economic costs and benefits of the CDM in EU-Vietnam relations provides valuable lessons in that regard.

In Chapter 7, 'The role and dynamics of the Clean Development Mechanism in EU-Vietnam climate relations', David Belis uncovers the details of the processes and actors involved. To that end, a conceptual tool is introduced that is specifically constructed to enhance empirical studies of CDM project design and CER flows: the CDM Design Classification Tool (CDM-DCT). This tool focuses on variations in design 'styles', based on built-in flexibilities regarding the number and place of origin of CDM project participants, CER sale and involvement of consultancy companies in the project development process. This chapter also contributes to the ongoing discussions on the future of the CDM or CDM-like mechanisms, in the context of international negotiations. In view of the EU's ban on credit imports from post-2012 CDM projects in non-LDCs, the future role of the CDM in EU-Vietnam and EU-Asia relations is set to be drastically reduced. Important lessons can nevertheless be drawn from the processes and particulars of EU-Vietnam CDM relations, as important points of reference for other bilateral climate relations, for the different business and government actors involved and for EU-Asia and global climate governance in general.

Another important contribution, Chapter 8, focuses on the regulatory framework for the CDM in the context of Vietnam's efforts to tackle 
climate change. In 'The Vietnamese regulatory framework for the Clean Development Mechanism', Nguyen Quang Thuan and Tran Thi Thu Huyen start from the observation that Vietnam, as a developing country, has had as its prime goal the achievement of rapid economic development and industrialization, in the context of its ongoing modernization and integration with the world economy. It is also one of the developing countries that aspires to be among the most active participants in climate adaptation and climate mitigation activities worldwide. As regards the international aspect, the UNFCCC and the Kyoto Protocol were signed by Vietnam on 11 June 1994 and on 3 December 1998, respectively, showing its willingness to embrace early international action. In that context, the authors present an analysis of Vietnam's experience with the CDM and the regulatory framework for the mechanism in Vietnam. The chapter formulates a number of recommendations to improve the functioning of the mechanism from a governance and regulatory perspective.

In Chapter 9, 'Public-private partnerships in CDM implementation in Vietnam', Dinh Thi Ngoc Bich and Sarah Van Eynde look at how project developers from the private and governmental sector come together to set up successful CDM partnerships in Vietnam. Public-private partnerships (PPPs) have been developed as key tools for increasing the effectiveness of public policy all over the world since the 1980s-1990s. With regard to climate governance, partnerships are found in the form of global public policy networks, network management, cooperative management regimes, interactive or cooperative environment management, voluntary cross-sectoral collaborations and environmental non-governmental organization (NGO)-business collaborative partnerships or green alliances. In light of the acknowledgement of the private sector's increased engagement in global environmental governance, Dinh and Van Eynde approach the CDM as a PPP and develop a theoretical framework for analysing PPPs in CDM implementation in Vietnam. The analysis aims at developing in-depth understanding of the complex PPP process in the CDM. This process of CDM implementation in Vietnam is portrayed based on three main aspects: input, throughput and output. From this perspective, the chapter assesses the PPP model's potential for explaining both CDM implementation in Vietnam and its effectiveness in terms of process performance, taking into account the CDM's multiple participants, their resources, institutional backgrounds and incentives.

In Chapter 10, 'Opportunities and challenges for Vietnamese enterprises involved in the CDM', Nguyen An Ha and Dang Minh Duc present a comprehensive assessment of opportunities and challenges for Vietnamese enterprises involved in the CDM, based on extensive fieldwork data. The chapter offers an analysis of the present status of and opportunities, dif- 
ficulties and potential for Vietnamese enterprises in implementing CDM projects. Various industrial sectors in Vietnam have taken initial steps in researching and formulating potential CDM projects in areas such as energy conservation and saving, conversion and usage of fossil fuels, capturing and utilizing methane gas from waste and coal mining, renewable energy, afforestation and reforestation, capturing and utilizing biogas and so forth. Businesses were particularly successful in establishing CDM projects in Vietnam's booming hydropower sector. In that context, this chapter provides valuable first-hand insight into the functioning of the CDM in Vietnam from a business perspective and provides recommendations to policymakers and professionals on how to facilitate (future) climate mitigation efforts in Vietnam.

The final chapter of Part II, Chapter 11, 'Case-study of Vietnamese hydropower CDM projects: shortcomings and barriers', discusses the environmental integrity of Vietnam's hydropower CDM projects. Sarah Van Eynde, Lieven De Smet and Nguyen An Ha firstly present the current state-of-the-art of these critiques in the literature, questioning the CDM's environmental effectiveness, economic efficiency and regulatory functioning, and secondly, provide evidence from the case of Vietnam, contributing to this evaluative literature and to the general literature on CDM governance. In particular, this chapter illustrates, on the basis of case-study research, that a significant number of Vietnamese hydropower CDM projects do not fully live up to the dual objective of GHG abatement and sustainable development. Through an assessment of the CDM's contribution to the transition in Vietnam towards a sustainable low-carbon society and through an environmental integrity analysis of 85 hydropower projects, Van Eynde, De Smet and Nguyen highlight a number of shortcomings in the CDM governance system and identify existing barriers to the establishment of an inclusive low-carbon economy in Vietnam through this type of climate mitigation instrument.

In Part III, the concluding Chapter 12, the book's key findings are summarized and interpreted in the context of current developments in global climate governance. The climate regime has entered a 'pivotal decade', with $2010-2020$ as a time horizon proposed by climate scientists as a final window of opportunity for tackling climate change. The various contributions in this book draw on first-hand empirical evidence to elucidate the content and processes of EU-China and EU-Vietnam climate relations, and highlight existing differences and similarities between these two cases. In doing so, the book also sets a future research agenda in the field of global environmental and climate politics. It is our view that a comprehensive understanding of the key issues and actors involved is essential in order to find politically feasible and environmentally effective instruments 
and overarching international (climate change or other environmental) agreements. Different pathways towards successful cooperation need to be explored in the current absence of strong global policies. This book, therefore, examines the climate regime in one of its most basic dimensions: that of an intrinsically relational and continually changing social reality, in the context of a globalizing and restructuring world order.

\section{REFERENCES}

Adams, F. Gerard and Anh Le Tran (2011), 'The competitiveness of Vietnam on the East Asian production ladder', International Journal of Business and Social Science, 2 (14), 82-95.

Adger, Neil W., Mick P. Kelly and Huu N. Nguyen (eds) (2001), Living with Environmental Change: Social Vulnerability, Adaptation and Resilience in Vietnam, London, UK and New York, USA: Routledge.

Andersen, Mikael Skou and Paul Ekins (eds) (2009), Carbon-Energy Taxation: Lessons from Europe, New York: Oxford University Press.

Asian Development Bank (2009), The Economics of Climate Change in Southeast Asia: A Regional Review, Manila: Asian Development Bank.

Belis, David and Hans Bruyninckx (2010), 'The European Union, Vietnam and the Clean Development Mechanism: a multi-level and multi-actor approach', European Studies Review, 11 (1), 41-61.

Belis, David and Simon Schunz (2012), 'Global climate governance and the energy challenge: European and Chinese perspectives', in Jan Wouters, Tanguy de Wilde, Pierre Defraigne and Jean-Christophe Defraigne (eds), China, the European Union and Global Governance, Cheltenham, UK and Northampton, MA, USA: Edward Elgar Publishing, pp. 201-214.

Beresford, Melanie (2008), 'Doi moi in review: the challenges of building market socialism in Vietnam', Journal of Contemporary Asia, 38 (2), 221-243.

Biermann, Frank (2005), 'Between the USA and the South: strategic choices for European climate policy', Climate Policy, 5 (3), 273-290.

Biermann, Frank (2006), 'Global governance and the environment', in Michele Betsill, Kathryn Hochstetler and Dimitris Stevis (eds), International Environmental Politics, Basingstoke, UK and New York, USA: Palgrave Macmillan, pp. 237-261.

Bodansky, Dan (1993), 'The United Nations Framework Convention on Climate Change: a commentary', Yale Journal of International Law, 18 (2), 451-558.

Böhm, Steffen and Siddhartha Dabhi (eds) (2010), Upsetting the Offset: The Political Economy of Offset Markets, London: MayFlyBooks.

Boyle, Grant, Jennifer Kirton, Rudi M. Lof and Tanya Nayler (2009), 'Transitioning from the CDM to a Clean Development Fund', Carbon and Climate Law Review, 1, 16-24.

BP (2012), BP Statistical Review of World Energy, June, London: BP.

Bruyninckx, Hans (2010), 'Living in a low-carbon society: a sociological perspective', presentation, High-level Workshop on Living in a Low-Carbon Society, 18-19 November, Brussels: European Commission and European Parliament. 
Bruyninckx, Hans, Sue Basu, Simon Schunz and Jan Wouters (2011), 'The position(s) of the EU in the UN system: the examples of human rights and environmental governance', in Jan Wouters, Hans Bruyninckx, Sue Basu and Simon Schunz (eds), The European Union and Multilateral Governance: Assessing EU Participation in United Nations Human Rights and Environmental Fora, Basingstoke, UK and New York, USA: Palgrave Macmillan, pp. 253-282.

Bulkeley, Harriet (2011), 'Cities and subnational governments', in John S. Dryzek, Richard B. Norgaard and David Schlosberg (eds), Oxford Handbook of Climate Change and Society, New York: Oxford University Press, pp. 464478.

Cao, Jing (2011), 'Exploring carbon tax in China', in Gang Fan, Nicholas Stern, Ottmar Edenhofer, Shanda Xu, Klas Eklund, Frank Ackerman, Lailai Li and Karl Hallding (eds), The Economics of Climate Change in China: Towards a Low-Carbon Economy, London, UK and Washington, DC, USA: Earthscan, pp. 213-230.

Carbon Market Institute (2012), Carbon Market Integrity: Integrity and Oversight of the European Union Emissions Trading System, East Melbourne: Carbon Market Institute.

Carter, Neil T. and Arthur P.J. Mol (eds) (2007), Environmental Governance in China, Abingdon, UK and New York, USA: Routledge.

Chang, Pei-fei, David Belis and Hans Bruyninckx (2012), 'EU-China climate relations: the Clean Development Mechanism and renewable energy in China', in Jan Wouters, Tanguy de Wilde, Pierre Defraigne and Jean-Christophe Defraigne (eds), China, the European Union and Global Governance, Cheltenham, UK and Northampton, MA, USA: Edward Elgar Publishing, pp. 227-244.

Chaponnière, Jean-Raphael, Jean-Pierre Cling and Bin Zhou (2008), Vietnam Following in China's Footsteps: The Third Wave of Emerging Asian Economies, research paper no. 2008/84, Helsinki: World Institute for Development Economics Research, United Nations University.

CIA (Central Intelligence Agency) (2012), 'The World Factbook: Vietnam', https://www.cia.gov/library/publications/the-world-factbook/geos/vm.html, accessed 13 August 2012.

Cole, John C. (2012), 'Genesis of the CDM: the original policymaking goals of the 1997 Brazilian proposal and their evolution in the Kyoto protocol negotiations into the CDM', International Environmental Agreements: Politics, Law and Economics, 12 (1), 41-61.

Conrad, Björn (2012), 'China in Copenhagen: reconciling the "Beijing climate revolution" and the "Copenhagen climate obstinacy", China Quarterly, 210, 435-455.

Cooper, Richard (2012), 'China-EU and the challenge of global climate change and energy', in Jan Wouters, Tanguy de Wilde, Pierre Defraigne and JeanChristophe Defraigne (eds), China, the European Union and Global Governance, Cheltenham, UK and Northampton, MA, USA: Edward Elgar Publishing, pp. 215-218.

De Cock, Geert (2011), 'The European Union as a bilateral "norm leader" on climate change vis-à-vis China', European Foreign Affairs Review, 16 (1), 89-105.

De Matteis, Pietro (2010), 'EU-China cooperation in the field of energy, environment and climate change', Journal of Contemporary European Research, 6 (4), 449-477.

Delbeke, Jos (ed.) (2006), EU Energy Law, Volume IV EU Environmental Law, The EU Greenhouse Gas Emissions Trading Scheme, Leuven: Claeys \& Casteels. 
Dryzek, John S., Richard B. Norgaard and David Schlosberg (2011), Oxford Handbook of Climate Change and Society, New York: Oxford University Press.

EEAS (European External Action Service) (2007), Vietnam-European Community Strategy Paper for the period 2007 to 2013, EEAS Report, Brussels: EEAS.

EEAS (2009), Mid-Term Review of the Strategy 2007-2013 and Multi-annual Indicative Programme 2011-2013, EEAS Report, Brussels: EEAS.

EIA (US Energy Information Administration) (2012), 'International Energy Statistics', http://www.eia.gov/countries/data.cfm\#undefined, accessed 17 October 2012.

EIB (European Investment Bank) (2009), 'EIB Vietnam Climate Change Framework Loan', http://www.eib.org/projects/pipeline/2008/20080266.htm, accessed 1 August 2012.

Enright, Michael J., Edith E. Scott and Ka-mun Chang (2005), Regional Powerhouse: The Greater Pearl River Delta and the Rise of China, Singapore: John Wiley \& Sons.

European Commission (2009), 'EU action against climate change: the EU Emissions Trading Scheme', http://ec.europa.eu/clima/publications/docs/ets_ en.pdf, accessed 13 August 2012.

European Commission (2012), Commissioner Piebalgs in Vietnam to Meet President and Discuss Future Cooperation, press release, 28 March, Brussels: European Commission.

European Union (2005), EU and China Partnership on Climate Change, MEMO/05/298, 2 September, Brussels: European Union.

European Union (2009a), 'Directive 2009/29/EC of the European Parliament and of the Council of 23 April 2009 amending Directive 2003/87/EC so as to improve and extend the greenhouse gas emission allowance trading scheme of the Community', Official Journal of the European Union, 5 June, http://eur-lex. europa.eu, accessed 1 June 2012.

European Union (2009b), 'Decision 406/2009/EC of the European Parliament and of the Council of 23 April 2009 on the effort of Member States to reduce their greenhouse gas emissions to meet the Community's greenhouse gas emission reduction commitments up to 2020', Official Journal of the European Union, 5 June, http://eur-lex.europa.eu, accessed 1 June 2012.

European Union (2012), EU Relations with China: EU-China Summit Factsheet (Beijing, 14 February 2012), MEMO/12/85, press release, 8 February, Brussels: European Union.

Falkner, Robert, Hannes Stephan and John Vogler (2010), 'International climate policy after Copenhagen: towards a "building blocks" approach', Global Policy, 1 (3), 252-262.

Fan, Gang, Nicholas Stern, Ottmar Edenhofer, Shanda Xu, Klas Eklund, Frank Ackerman, Lailai Li and Karl Hallding (eds) (2011), The Economics of Climate Change in China: Towards a Low-Carbon Economy, London, UK and Washington, DC, USA: Earthscan.

Fforde, Adam (2009), 'Economics, history and the origins of Vietnam's post-war economic success', Asian Survey, 49 (3), 484-504.

Fortier, François (2010), 'Taking a climate chance: a procedural critique of Vietnam's climate change strategy', Asia Pacific Viewpoint, 54 (3), 229-247.

Fox, John and François Godement (2009), A Power Audit of EU-China Relations, policy report, London: European Council on Foreign Relations. 
Grubb, Michael (2010), 'Copenhagen: back to the future', Climate Policy, 10 (2), 127-130.

Grubb, Michael, Christiaan Vrolijk and Duncan Brack (1999), The Kyoto Protocol. $A$ Guide and Assessment, London: Royal Institute of International Affairs.

Gupta, Joyeeta and Lasse Ringius (2001), 'Climate leadership: reconciling ambition and reality', International Environmental Agreements: Politics, Law and Economics, 1 (2), 281-299.

Harris, Paul G. (ed.) (2000), Climate Change and American Foreign Policy, New York: St Martin's Press.

Harris, Paul G. (ed.) (2005), Confronting Environmental Change in East \& Southeast Asia: Eco-politics, Foreign Policy, and Sustainable Development, Tokyo, Japan, New York, USA and Paris, France: United Nations University Press.

Harris, Paul G. (ed.) (2007), Europe and Global Climate Change: Politics, Foreign Policy and Regional Cooperation, Cheltenham, UK and Northampton, MA, USA: Edward Elgar Publishing.

Harris, Paul G. (2011), 'Chinese responsibility for climate change', in Paul G. Harris (ed.), China's Responsibility for Climate Change: Ethics, Fairness and Environmental Policy, Bristol: Policy Press, pp. 1-24.

Heggelund, Gørild and Ellen B. Backer (2007), 'China and UN environmental policy: institutional growth, learning and implementation', International Environmental Agreements: Politics, Law and Economics, 7 (4), 415-438.

Herberg, M.E. (2009), 'Fuelling the dragon: China's energy prospects and international implications', in A. Wenger, R. Ortung and J. Perovic (eds), Energy and the Transformation of International Relations, Oxford: Oxford University Press, pp. 269-297.

Hugé, Jean, Le T. Hai, Hoang H. Pham, Jan Kuilman and Luc Hens (2010), 'Sustainability indicators for Clean Development Mechanism projects in Vietnam', Environment, Development and Sustainability, 12 (4), 561-571.

IEA (International Energy Agency) (2011), World Energy Outlook 2011, Paris: IEA.

IPCC (Intergovernmental Panel on Climate Change) (2007), Climate Change 2007: Impacts, Adaptation and Vulnerability, Contribution of Working Group II to the Fourth Assessment Report of the Intergovernmental Panel on Climate Change, Martin L. Parry, Osvaldo F. Canziani, Jean P. Palutikof, Paul J. van der Linden and Clair E. Hanson (eds), Cambridge: Cambridge University Press.

Jordan, Andrew, Dave Huitema, Harro Van Asselt, Tim Rayner and Frans Berkhout (eds) (2010), Climate Change Policy in the European Union, Cambridge: Cambridge University Press.

Keukeleire, Stephan and Hans Bruyninckx (2011), 'The European Union, the BRICs and the emerging new world order', in Christopher Hill and Michael Smith (eds), International Relations and the European Union, Oxford: Oxford University Press, pp. 380-403.

Korppoo, Anna and Alex Luta (eds) (2009), Towards a New Climate Regime? Views of China, India, Japan, Russia and the United States on the Road to Copenhagen, Helsinki: Finnish Institute of International Affairs.

Kreiser, Larry, Julsuchada Sirisom, Hope Ashiabor and Janet E. Milne (eds) (2011), Environmental Taxation and Climate Change: Achieving Environmental Sustainability through Fiscal Policy, Cheltenham, UK and Northampton, MA, USA: Edward Elgar Publishing.

Lütken, Søren E. (2012), Penny Wise, Pound Foolish? Is the Original Intention of 
Cost Efficient Emissions Reduction through the CDM Being Fulfilled?, UNEP Risø Climate working paper series no. 1, June, Roskilde: UNEP Risø Centre.

Lütken, Søren E. and Axel Michaelowa (2008), Corporate Strategies and the Clean Development Mechanism: Developing Country Financing for Developed Country Commitments?, Cheltenham, UK and Northampton, MA, USA: Edward Elgar Publishing.

McKinsey Global Institute (2012), Sustaining Vietnam's Growth: The Productivity Challenge, Hanoi: McKinsey Global Institute.

Meckling, Jonas (2011), 'The globalization of carbon trading: transnational business coalitions in climate politics', Global Environmental Politics, 11 (2), 26-50.

MOF (Ministry of Foreign Affairs of the People's Republic of China) (2006), China-EU Partnership on Climate Change Rolling Work Plan, press release, 19 October, Beijing: MOF.

Mol, Arthur P.J. and Joost van Buuren (eds) (2003), Greening Industrialization in Asian Transitional Economies: China and Vietnam, Oxford: Lexington Books.

National Bureau of Statistics of China (2012), 中国统计年鉴 2012 Zhongguo tongji nianjian 2012 [China Statistical Yearbook 2012], Beijing: China Statistics Press.

Nguyen, An H. and Minh D. Dang (2010), 'The implementation of the CDM in Vietnam from a business perspective', European Studies Review, 11 (1), 31-40.

Nguyen, Nhan T., Ha-Duong Minh, Sandra Greiner and Michael Mehling (2010), 'Improving the Clean Development Mechanism post-2012: a developing country perspective', Carbon and Climate Law Review, 4 (1), 76-85.

Nguyen, Quang T. and Thi T.H. Tran (2010), 'The Clean Development Mechanism (CDM) and its legal framework in Vietnam', European Studies Review, 11 (1), $16-31$.

Oberthür, Sebastian and Hermann E. Ott (1999), The Kyoto Protocol. International Climate Policy for the 21 st Century, Berlin: Springer.

Oberthür, Sebastian and Marc Pallemaerts (eds) (2010), The New Climate Policies of the European Union: Internal Legislation and Climate Diplomacy, Brussels: Brussels University Press.

Point Carbon (2012), Carbon 2012: A Market Waiting for Godot, Carina Heimdal, Emil Dimantchev, Hongliang Chai, Emilie Mazzacurati, Anders Nordeng, Ingvild Sørhus, Natalia Yakymenko and Elizabeth Zelljadt (eds), Oslo: Point Carbon.

Qi, Ye (ed.) (2011), 中国低碳发展报告 (2011-2012) Zhongguo ditan fazhan baogao (2011-2012) [Annual Review of Low Carbon Development in China (2011-2012) ], Beijing: Social Sciences Academic Press.

Qi, Ye, Li Ma, Huanbo Zhang and Huimin Li (2008), 'Translating a global issue into local priority: China's local government response to climate change', Journal of Environment and Development, 17 (4), 379-400.

Ruthner, Lena, Mark Johnson, Bipasha Chatterjee, Michael Lazarus, Noriko Fujiwara, Christian Egenhofer, Tanguy du Monceau and Arnaud Brohe (2011), Study on the Integrity of the Clean Development Mechanism (CDM). Report CLIMA.B.3/ETU/2010/0020r for the European Commission, Directorate General Climate Action, London: AEA.

Schreurs, Miranda (2008), 'From the bottom up: local and subnational climate change politics', Journal of Environment and Development, 17 (4), 343-355.

Schreurs, Miranda (2010), 'Multi-level governance and global climate change in East Asia', Asian Economic Policy Review, 5 (1), 88-105. 
Schröder, Miriam (2012), Local Climate Governance in China: Hybrid Actors and Market Mechanisms, Basingstoke: Palgrave Macmillan.

Skjærseth, Jon B. (2010), 'EU emissions trading: legitimacy and stringency', Environmental Policy and Governance, 20 (5), 295-308.

Skjærseth, Jon B. and Jørgen Wettestad (2009), 'The origin, evolution and consequences of the EU Emissions Trading System', Global Environmental Politics, 9 (2), 101-122.

Sonnenfeld, David A. and Arthur P.J. Mol (2010), 'Urban and industrial environmental reform in Southeast Asia', in Rajah Rasiah and Johannes D. Schmidt (eds), The New Political Economy of Southeast Asia, Cheltenham, UK and Northampton, MA, USA: Edward Elgar Publishing, pp. 198-228.

Spaargaren, Gert, Arthur P.J. Mol and Hans Bruyninckx (2006), 'Introduction: governing environmental flows in global modernity', in Gert Spaargaren, Arthur P.J. Mol and Frederick H. Buttel (eds), Governing Environmental Flows: Global Challenges to Social Theory, Cambridge: MIT Press, pp.1-36.

Stern, Nicholas (2007), The Economics of Climate Change: The Stern Review, Cambridge: Cambridge University Press.

Thayer, Carlyle A. (2010), 'Vietnam and rising China: the structural dynamics of mature asymmetry', Southeast Asian Affairs, 2010 (1), 392-409.

Tønnesson, Stein (2009), 'Energy security and climate change: the potential role of China and India', in Gunnar Fermann (ed.), Political Economy of Energy in Europe: Forces of Fragmentation and Integration, Berlin: Berliner Wissenschaftsverlag, pp. 188-220.

UNFCCC (United Nations Framework Convention on Climate Change) (2010), Report of the Conference of the Parties on its Fifteenth Session, Held in Copenhagen from 7 to 19 December 2009: Addendum, FCCC/CP/2009/11/Add.1, Bonn: UNFCCC.

UNFCCC (2011a), Report of the Conference of the Parties on its Sixteenth Session, Held in Cancun from 29 November to 10 December 2010: Addendum, FCCC/ CP/2010/7/Add.1, Bonn: UNFCCC.

UNFCCC (2011b), Establishment of an Ad Hoc Working Group on the Durban Platform for Enhanced Action, FCCC/CP/2011/L.10, Bonn: UNFCCC.

UNFCCC (2012), 'CDM in numbers', http://cdm.unfccc.int/Statistics/index.html, accessed 13 August 2012.

United Nations (1992), United Nations Framework Convention on Climate Change, New York: United Nations.

United Nations (1998), Kyoto Protocol to the United Nations Framework Convention on Climate Change, New York: United Nations.

United Nations (2012), Benefits of the Clean Development Mechanism 2012, New York: United Nations.

Van Asselt, Harro and Joyeeta Gupta (2009), 'Stretching too far? Developing countries and the role of flexibility mechanisms beyond Kyoto', Stanford Environmental Law Journal, 28 (2), 311-379.

Walsh, Sean, Huifang Tian, John Whalley and Manmohan Agarwal (2011), 'China and India's participation in global climate negotiations', International Environmental Agreements: Politics, Law and Economics, 11 (3), 261-273.

Wara, Michael (2008), 'Measuring the Clean Development Mechanism's performance and potential', UCLA Law Review, 55 (6), 1759-1803.

Wara, Michael and David G. Victor (2008), A Realistic Policy on International 
Carbon Offsets, Programme on Energy and Sustainable Development working paper 74, Stanford, CA: Stanford University.

World Bank (2012a), 'World Bank data indicators', http://data.worldbank.org/ indicator, accessed 13 August 2012.

World Bank (2012b), Taking Stock: An update on Vietnam's Recent Economic Development, Washington, DC: World Bank.

Wouters, Jan, Tanguy de Wilde, Pierre Defraigne and Jean-Christophe Defraigne (eds) (2012), China, the European Union and Global Governance, Cheltenham, UK and Northampton, MA, USA: Edward Elgar Publishing.

Wurzel, Rüdiger and James Connelly (eds) (2011), The European Union as a Leader in International Climate Change Politics, New York: Routledge.

Yamin, Farhana (ed.) (2005), Climate Change and Carbon Markets: A Handbook of Emissions Reduction Mechanisms, London and Sterling: Earthscan.

Zeng, Shaojun (2010), 碳减排: 中国经验 Tan jianpai: Zhongguo jingyan [Carbon Emission Reductions: China's Experiences], Beijing: Social Sciences Academic Press.

Zhang, Zhongxiang (2011a), Energy and Environmental Policy in China: Towards a Low-Carbon Economy, Cheltenham, UK and Northampton, MA, USA: Edward Elgar Publishing.

Zhang, Zhongxiang (2011b), 'In what format and under what timeframe would China take on climate commitments? A roadmap to 2050', International Environmental Agreements: Politics, Law and Economics, 11 (3), 245-259. 